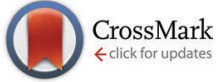

Cite this: New J. Chem., 2017, 41, 2198

Received 8th December 2016 Accepted 6th February 2017

DOI: $10.1039 / c 6 n j 03844 a$

rsc.li/njc

\title{
Salan group 13 complexes - structural study and lactide polymerisation $\dagger$
}

\author{
James Beament, Mary F. Mahon, Antoine Buchard* and Matthew D. Jones*
}

\begin{abstract}
Herein the preparation and characterisation of a series of group 13 salan complexes, with a bipyrrolidine or $\mathrm{N}, \mathrm{N}^{\prime}$-ethylenediamine backbone are disclosed. For the bipyrrolidine derived-salan ligand $\mathbf{1} \mathrm{H}_{2}$, the $\mathrm{Al}($ III) and $\mathrm{Ga}$ (III) complexes are pseudo trigonal bipyramidal in the solid-state, whereas the $\operatorname{In}($ (II) complexes are best described as square based pyramidal structures. However, for the ethylenediamine derived-salan ligand $\mathbf{2} \mathrm{H}_{2}$, all complexes are effectively square based pyramidal in their structure. The complexes' solution behaviour is also investigated by NMR spectroscopic methods and it is observed that the solid-state structure is maintained in solution. The complexes have all been trialled for the ring opening polymerisation of rac-lactide. With $\ln (\mathbf{1}) \mathrm{Cl}$ controlled polymerisation and narrow molecular weight distributions (1.01-1.08) are observed with heterotactic polylactide being prepared. Under the conditions tested the $\mathrm{Ga}($ III) and $\mathrm{Al}(\mathrm{III})$ complexes were shown to be inactive.
\end{abstract}

\section{Introduction}

In recent years there has been an explosion of research concerning new initiators for the controlled ring opening polymerisation (ROP) of lactide (LA) affording polylactide (PLA). ${ }^{1}$ The resultant PLA is compostable and annually renewable from starch-rich plant based materials. This material has the potential to replace traditional petrochemical derived plastics for numerous applications, from high value biomedical areas to commodity uses. ${ }^{2}$ While organocatalysts and initiators commonly yield atactic PLA from $\mathrm{rac}$-LA, ${ }^{3}$ there are many metal centres that are active for the stereoselective polymerisation of $r a c$-LA to afford either heterotactic or isotactic stereoblock PLA. Examples of such metal centres include groups $1-4,{ }^{4}$ lanthanides, $\mathrm{Zn}(\mathrm{II})^{4 f, 5}$ and pertinent to this study group 13 metals. ${ }^{6}$ There are many ligands that have found utility in this area such as salan, ${ }^{4 a, b, 6 b, c}$ salen, ${ }^{6 e-h, 7}$ salalen $^{8}$ and variations thereof, including phosphasalen. ${ }^{9}$ In the case of indium the area is dominated by salen ligands. ${ }^{10}$ However, other ligand systems are known. ${ }^{11} \mathrm{InCl}_{3}$ alone was first shown to be an active catalyst by Tolman and Hillmyer in 2009 , with high heterotacticity being favoured in THF solution, when used in combination with triethylamine and benzylalcohol. ${ }^{12}$ Recently, extensive studies have been conducted by Mehrkhodavandi and co-workers who have elegantly illustrated the advantages of In(III) complexes for the controlled ROP of rac-LA. ${ }^{7,13}$ These have typically utilised

Department of Chemistry, University of Bath, Claverton Down, Bath BA2 7AY, UK. E-mail: mj205@bath.ac.uk, a.buchard@bath.ac.uk; Fax: +44 (0)1225 386231;

Tel: +44 (0)1225 384908

$\dagger$ Electronic supplementary information (ESI) available: Full experimental and the crystal data in the .cif format. CCDC 1510494-1510501. For ESI and crystallographic data in CIF or other electronic format see DOI: 10.1039/c6nj03844a salen ligands with chirality in the backbone. For example, when indium is complexed with Jacobsen's ligand the resultant complex was seen to be faster than the corresponding $\mathrm{Al}$ (III) system, with isotactic $\left(P_{\mathrm{m}}=0.77\right)$ PLA being realised. ${ }^{13 a}$ In these studies aggregation of the indium complexes, due to the large ionic radii of In(III), ${ }^{13 i}$ has be shown to be troublesome, and was controlled by the use of bulky ligands. Ga(III) initiated ROP of lactide is rare with only a handful of examples reported in the literature. ${ }^{10,14}$ Further, complexes of In-"salan-like" ligands characterised in the solid-state are extremely rare. ${ }^{15}$ Thus, it is pertinent to study the coordination chemistry of simple salan related ligands with $\mathrm{In}(\mathrm{III})$ (to compare with $\mathrm{Al} / \mathrm{Ga}$ ) and screen for the ROP of rac-LA.

New catalyst research in the area is driven by the need to develop structure-activity-relationships and understand the complex interplay between the ligand and the metal centre, such relationships are lacking in the area. It has been shown that very subtle changes to the ligand or switching the metal centre can have dramatic consequences to the polymerisation. For example, we have shown with a bipyrrolidine derived salan ligand there is a switch in selectivity from highly isotactic PLA $\mathrm{Zr}$ (Iv)/Hf(Iv) to highly heterotactic PLA for $\mathrm{Al}(\mathrm{III}) .{ }^{4 a}$ Williams and co-workers have observed similar switches with phosphasalen complexes of different lanthanides. ${ }^{16}$ Further switching in control are noted by comparing Al-(SalBinap) (isotactic) to Y(SalBinap) (heterotactic) complexes of Coates and Pappalardo respectively. ${ }^{17}$ Kol first introduced the bipyrrolidine ligand in 2009 to pre-determine the chirality at a group 4 metal centre. ${ }^{18} \mathrm{We}$ have previously illustrated that ligands based on the bipyrrolidine backbone are highly effective for the ROP of lactide. ${ }^{4 a, b}$ More recently, Kol has also utilised this backbone with $\mathrm{Mg}$ (II) and to 
some extent $\mathrm{Al}(\mathrm{III})$, highlighting the importance of these ligands in the literature. ${ }^{19}$ We have shown the importance of the meso chirality, in the controlled and selective polymerisation of lactide. ${ }^{4 a, b}$ Thus, in this paper we expand upon the chemistry of this system and report the full characterisation of a series of group 13 complexes with our bulky salan derived mesobipyrrolidine ligand and an $N, N^{\prime}$-ethylenediamine backbone for comparison. To the best of our knowledge this is also the first reported application of a monomeric In-salan complex for the ROP of rac-LA.

\section{Experimental}

\section{General considerations}

The preparation and characterisation of all metal complexes was carried out under an inert argon atmosphere using standard Schlenk or glovebox techniques. All chemicals used were purchased from Sigma-Aldrich and used as received except for rac-LA which was recrystallized twice from dry toluene before use. Dry solvents used in handling metal complexes were obtained via SPS (solvent purification system). ${ }^{1} \mathrm{H}$ and ${ }^{13} \mathrm{C}\left\{{ }^{1} \mathrm{H}\right\}$, NMR spectra were recorded on a Bruker 400 or $500 \mathrm{MHz}$ instrument and referenced to residual solvent peaks. $\mathrm{CDCl}_{3}$ was dried over $\mathrm{CaH}_{2}$ prior to use. Coupling constants are given in Hertz. CHN microanalysis was performed by Mr Stephen Boyer of London Metropolitan University. The ligands were prepared as detailed in the literature..$^{4 a, 20}$

\section{Synthesis of complexes}

In a typical experiment: ligand $\left(\mathbf{1 H}_{2}\right)(2.6 \mathrm{mmol})$ dissolved in THF $(10 \mathrm{~mL})$ was added dropwise to a stirred suspension of potassium hydride $(5.2 \mathrm{mmol})$ in THF $(10 \mathrm{~mL})$ and stirred for 16 hours. The solution was then cooled to $-78{ }^{\circ} \mathrm{C}$ and a solution of $\mathrm{InCl}_{3}(2.6 \mathrm{mmol})$ in anhydrous THF $(10 \mathrm{~mL})$ was added dropwise and after complete addition, the solution was left to stir for a further 2 hours. After this time, the solvent was removed and the white powder was dissolved in dry chloroform and filtered through a pad of celite under Ar. The supernatant was collected and removal of solvent yielded the crude product, which was then recrystallised in dry hexane/toluene. $\operatorname{In}(\mathbf{1}) \mathrm{Cl}$ yield: (1.61 g, $2.22 \mathrm{mmol}, 85 \%) .{ }^{1} \mathrm{H}-\mathrm{NMR}\left(400 \mathrm{MHz}, \mathrm{CDCl}_{3}, \delta_{\mathrm{H}}\right.$, ppm); 7.30 (s, 2H; ArH), 6.76 (s, 2H; ArH), 4.73 (d, $12.7 \mathrm{~Hz}, 2 \mathrm{H}$, $\mathrm{NCHHC}$ ), 3.41 (d, 2H, $2.5 \mathrm{~Hz}$; NCH), 3.34 (d, 2H, $12.7 \mathrm{~Hz}$; $\mathrm{NCH} H \mathrm{C}), 3.10\left(\mathrm{~m}, 2 \mathrm{H} ; \mathrm{CH}_{2} \mathrm{~N}\right), 3.00\left(\mathrm{~m}, 2 \mathrm{H} ; \mathrm{CH}_{2} \mathrm{~N}\right), 2.31(\mathrm{~m}$, $2 \mathrm{H} ; \mathrm{CHH}), 2.03\left(\mathrm{~m}, 4 \mathrm{H} ; \mathrm{CH}_{2}\right), 1.90(\mathrm{~m}, 2 \mathrm{H} ; \mathrm{CH}), 1.50(\mathrm{~s}, 18 \mathrm{H}$; $\left.\mathrm{C}\left(\mathrm{CH}_{3}\right)_{3}\right) 1.28\left(\mathrm{~s}, 18 \mathrm{H} ; \mathrm{C}\left(\mathrm{CH}_{3}\right)_{3}\right) ;{ }^{13} \mathrm{C}\left\{{ }^{1} \mathrm{H}\right\} \mathrm{NMR}\left(100 \mathrm{MHz}, \mathrm{CDCl}_{3}\right.$, $\left.\delta_{\mathrm{C}}, \mathrm{ppm}\right) ; 159.5(C-\mathrm{O}), 138.5(\mathrm{Ar}), 136.2(\mathrm{Ar}), 123.9(C-\mathrm{H}, \mathrm{Ar})$, $123.8(\mathrm{C}-\mathrm{H}, \mathrm{Ar}), 118.8(\mathrm{Ar}), 66.1(\mathrm{NCH}), 61.6\left(\mathrm{NCH}_{2}\right)$, $52.4\left(\mathrm{NCH}_{2}\right), 34.2\left(\mathrm{C}\left(\mathrm{CH}_{3}\right)_{3}\right), 32.9\left(\mathrm{C}\left(\mathrm{CH}_{3}\right)_{3}\right), 30.8\left(\mathrm{C}\left(\mathrm{CH}_{3}\right)_{3}\right)$, $28.7\left(\mathrm{C}\left(\mathrm{CH}_{3}\right)_{3}\right), 25.3\left(\mathrm{CH}_{2}\right), 20.1\left(\mathrm{CH}_{2}\right)$. Elemental analysis $\left(\mathrm{C}_{38} \mathrm{H}_{58} \mathrm{~N}_{2} \mathrm{O}_{2} \mathrm{In}_{1} \mathrm{Cl}_{1}\right)$, (calculated) C: $62.94 \%, \mathrm{H}: 8.06 \%, \mathrm{~N}$ : 3.86\% (experimental) C: $63.01 \%, \mathrm{H}: 8.08 \%, \mathrm{~N}: 3.86 \%$. $\mathrm{Al}(\mathbf{1}) \mathrm{Cl}$ (0.6 g, $0.94 \mathrm{mmol}, 55 \%) .{ }^{1} \mathrm{H}-\mathrm{NMR}$ (400 MHz, $\mathrm{CDCl}_{3}, \delta_{\mathrm{H}}, \mathrm{ppm}$ ); 7.23 (s, 2H; ArH), 6.73 (s, 2H; ArH), 4.45 (m, 2H; NCHHC), 3.32 (m, 6H; NCH), $2.84(\mathrm{~m}, 2 \mathrm{H} ; \mathrm{NCH} H \mathrm{C}), 2.17\left(\mathrm{~m}, 2 \mathrm{H} ; \mathrm{CH}_{2} \mathrm{~N}\right), 1.98$ $\left(\mathrm{m}, 2 \mathrm{H} ; \mathrm{CH}_{2} \mathrm{~N}\right), 1.86(\mathrm{~m}, 2 \mathrm{H} ; \mathrm{CHH}), 1.42\left(\mathrm{~s}, 18 \mathrm{H} ; \mathrm{C}\left(\mathrm{CH}_{3}\right)_{3}\right), 1.24$ (s, $\left.18 \mathrm{H} ; \mathrm{C}\left(\mathrm{CH}_{3}\right)_{3}\right) ;{ }^{13} \mathrm{C}\left\{{ }^{1} \mathrm{H}\right\}$ NMR $\left(100 \mathrm{MHz}, \mathrm{CDCl}_{3}, \delta_{\mathrm{C}}, \mathrm{ppm}\right)$; 156.2 (C-O), 138.4 (Ar), 138.1 (Ar), $124.4(C-\mathrm{H}, \mathrm{Ar}), 123.2(C-\mathrm{H}$, Ar), $120.4(\mathrm{Ar}), 67.8(\mathrm{NCH}), 62.3\left(\mathrm{NCH}_{2}\right), 54.5\left(\mathrm{NCH}_{2}\right), 35.3$ $\left(C\left(\mathrm{CH}_{3}\right)_{3}\right), 34.3\left(\mathrm{C}\left(\mathrm{CH}_{3}\right)_{3}\right), 32.1\left(\mathrm{C}\left(\mathrm{CH}_{3}\right)_{3}\right), 30.1\left(\mathrm{C}\left(\mathrm{CH}_{3}\right)_{3}\right), 27.0$ $\left(\mathrm{CH}_{2}\right), 21.8\left(\mathrm{CH}_{2}\right)$. Elemental analysis (CHN), (calculated) C: 71.61\%, H: 9.17\%, N: 4.39\% (experimental) C: 69.17\%, H: 9.12\%, $\mathrm{N}: 4.31 \%$.

$\mathrm{Ga}(\mathbf{1}) \mathrm{Cl}(0.93 \mathrm{~g}, 1.37 \mathrm{mmol}, 53 \%) .{ }^{1} \mathrm{H}-\mathrm{NMR}$ (400 MHz, $\mathrm{CDCl}_{3}$, $\left.\delta_{\mathrm{H}}, \mathrm{ppm}\right) ; 7.28(\mathrm{~s}, 2 \mathrm{H}, \mathrm{Ar}), 6.77(\mathrm{~s}, 2 \mathrm{H}, \mathrm{Ar}), 4.66(\mathrm{~d}, 2 \mathrm{H}, 12.2 \mathrm{~Hz}$, $\mathrm{NCHHC}$ ), 3.75 (d, 2H, $2.5 \mathrm{~Hz}, \mathrm{NCH}), 3.36$ (d, 2H, $12.2 \mathrm{~Hz}$, $\mathrm{NCH} H \mathrm{C}), 2.92\left(4 \mathrm{H}, \mathrm{m}, \mathrm{CH}_{2} \mathrm{~N}\right), 2.27(\mathrm{~m}, 2 \mathrm{H}, \mathrm{CHH}), 2.03(\mathrm{~m}$, $\left.4 \mathrm{H}, \mathrm{CH}_{2}\right), 1.90(\mathrm{~m}, 2 \mathrm{H}, \mathrm{CH} H), 1.48\left(\mathrm{~s}, 18 \mathrm{H},{ }^{t} \mathrm{Bu}\right), 1.28(\mathrm{~s}, 18 \mathrm{H}$, $\left.{ }^{t} \mathrm{Bu}\right) ;{ }^{13} \mathrm{C}\left\{{ }^{1} \mathrm{H}\right\}\left(100 \mathrm{MHz}, \mathrm{CDCl}_{3}, \delta_{\mathrm{C}}, \mathrm{ppm}\right) ; 158.5(C-\mathrm{O}), 139.2$ (Ar), 137.9 (Ar), 124.7 (C-H, Ar), 123.8 ( $C-\mathrm{H}, \mathrm{Ar}), 119.9(\mathrm{Ar}), 68.3$ $(\mathrm{NCH}), 67.2(\mathrm{NCH}), 62.6\left(\mathrm{NCH}_{2}\right), 54.2\left(\mathrm{NCH}_{2}\right), 35.5\left(\mathrm{C}\left(\mathrm{CH}_{3}\right)_{3}\right)$,

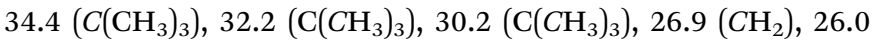
$\left(\mathrm{CH}_{2}\right), 21.5\left(\mathrm{CH}_{2}\right)$. Elemental analysis $(\mathrm{CHN})$, (calculated) $\mathrm{C}$ : $67.11 \%, \mathrm{H}: 8.60 \%, \mathrm{~N}: 4.12 \%$ (experimental) C: $66.82 \%, \mathrm{H}$ : 8.56\%, N: 4.64\%. In(1)I (345 mg, $0.42 \mathrm{mmol}, 42 \%) .{ }^{1} \mathrm{H}-\mathrm{NMR}$ $\left(400 \mathrm{MHz}, \mathrm{CDCl}_{3}, 253 \mathrm{~K}, \delta_{\mathrm{H}}, \mathrm{ppm}\right) ; 7.29$ (s, 2H; $\left.\mathrm{ArH}\right), 6.76(\mathrm{~s}, 2 \mathrm{H}$; $\mathrm{ArH}), 4.76$ (d, $12.7 \mathrm{~Hz}, 2 \mathrm{H}$; NCHHC), 3.53 (d, 2.5 Hz, 2H; NCH), 3.34 (d, $12.7 \mathrm{~Hz}, 2 \mathrm{H}$; NCHHC), 3.10 (m, 2H; $\left.\mathrm{CH}_{2} \mathrm{~N}\right), 2.97$ (m, 2H; $\left.\mathrm{CH}_{2} \mathrm{~N}\right), 2.31(\mathrm{~m}, 2 \mathrm{H} ; \mathrm{CHH}), 1.99\left(\mathrm{~m}, 4 \mathrm{H} ; \mathrm{CH}_{2}\right), 1.90(\mathrm{~m}, 2 \mathrm{H}$; $\mathrm{CH} H), 1.50\left(\mathrm{~s}, 18 \mathrm{H},\left(\mathrm{C}\left(\mathrm{CH}_{3}\right)_{3}\right)\right), 1.28\left(\mathrm{~s}, 18 \mathrm{H},\left(\mathrm{C}\left(\mathrm{CH}_{3}\right)_{3}\right)\right)$. ${ }^{13} \mathrm{C}-\mathrm{NMR}\left(100 \mathrm{MHz}, \mathrm{CDCl}_{3}, 298 \mathrm{~K}, \delta_{\mathrm{C}}, \mathrm{ppm}\right) ; 139.49(\mathrm{Ar}), 125.2$ $(\mathrm{Ar}), 67.5(\mathrm{NCH}), 54.16\left(\mathrm{NCH}_{2}\right), 52.4\left(\mathrm{NCH}_{2}\right), 35.3\left(\mathrm{C}\left(\mathrm{CH}_{3}\right)_{3}\right), 34.3$ $\left(C\left(\mathrm{CH}_{3}\right)_{3}\right), 32.1\left(\mathrm{C}\left(\mathrm{CH}_{3}\right)_{3}\right), 30.4\left(\mathrm{C}\left(\mathrm{CH}_{3}\right)_{3}\right), 27.0\left(\mathrm{CH}_{2}\right), 20.9\left(\mathrm{CH}_{2}\right)$. Elemental analysis (CHN), (calculated) C: $55.89 \%, \mathrm{H}: 7.16 \%, \mathrm{~N}$ : $3.43 \%$ (experimental) C: $56.05 \%, \mathrm{H}: 7.19 \%, \mathrm{~N}: 3.42 \% . \mathrm{Al}(2) \mathrm{Cl}$ (680 mg, $1.16 \mathrm{mmol}, 61 \%) .{ }^{1} \mathrm{H}-\mathrm{NMR}\left(400 \mathrm{MHz}, \mathrm{CDCl}_{3}, \delta_{\mathrm{H}}, \mathrm{ppm}\right)$ : (major series) 7.30 (s, 2H, Ar), 6.81 (s, 2H, Ar), 4.52-4.49 (d, $12.4 \mathrm{~Hz}, 2 \mathrm{H}, \mathrm{CH} H \mathrm{~N}$ ), 3.20 (d, $12.4 \mathrm{~Hz}, 2 \mathrm{H}, \mathrm{CHHN}), 2.98(\mathrm{~m}, 4 \mathrm{H}$, $\mathrm{NCH}_{2}$ ), 2.44 (s, 6H, $\left.\mathrm{NCH}_{3}\right), 1.47\left(\mathrm{~s}, 18 \mathrm{H},{ }^{t} \mathrm{Bu}\right), 1.29\left(\mathrm{~s}, 18 \mathrm{H},{ }^{t} \mathrm{Bu}\right)$, due to significant overlap in ${ }^{t} \mathrm{Bu}$, Ar region full assignment of minor series is not possible. But it is clear from the NMR below. ${ }^{13} \mathrm{C}-\mathrm{NMR}\left(100 \mathrm{MHz}, \mathrm{CDCl}_{3}, \delta_{\mathrm{C}}, \mathrm{ppm}\right): 155.7(C-\mathrm{O}), 138.6(\mathrm{Ar})$, 138.4 (Ar), $124.5(\mathrm{Ar}), 123.3(\mathrm{Ar}), 119.7(\mathrm{Ar}), 63.0\left(\mathrm{CH}_{2} \mathrm{~N}\right), 55.2$ $\left(\mathrm{CH}_{2} \mathrm{~N}\right), 45.6\left(\mathrm{NCH}_{3}\right), 35.5\left(C\left(\mathrm{CH}_{3}\right)_{3}\right), 34.2\left(C\left(\mathrm{CH}_{3}\right)_{3}\right), 32.0$ $\left(\mathrm{C}\left(\mathrm{CH}_{3}\right)_{3}\right), 30.1\left(\mathrm{C}\left(\mathrm{CH}_{3}\right)_{3}\right)$. Elemental analysis $(\mathrm{CHN})$ : (calculated) C: $69.77 \%, \mathrm{H}: 9.30 \%, \mathrm{~N}: 4.79 \%$ (experimental) C: $67.57 \%, \mathrm{H}$ : 9.50\%, N: 4.75\%. Ga(2)Cl (565 mg, $0.9 \mathrm{mmol}, 48 \%) .{ }^{1} \mathrm{H}-\mathrm{NMR}$ (400 $\mathrm{MHz}, \mathrm{CDCl}_{3}, \delta_{\mathrm{H}}, \mathrm{ppm}$ ): 7.31 (s, 2H, Ar), 6.80 (s, 2H, Ar), 4.71-4.68 (d, $12.1 \mathrm{~Hz}, 2 \mathrm{H}, \mathrm{CHHN}), 3.25-3.22$ (d, $12.1 \mathrm{~Hz}, 2 \mathrm{H}$, $\mathrm{CH} H \mathrm{~N}), 3.16\left(\mathrm{~m}, 2 \mathrm{H}, \mathrm{CH}_{2} \mathrm{~N}\right), 2.95\left(\mathrm{~m}, 2 \mathrm{H}, \mathrm{CH}_{2} \mathrm{~N}\right), 2.42(\mathrm{~s}, 6 \mathrm{H}$, $\left.\mathrm{CH}_{3}\right), 1.51$ (s, $\left.18 \mathrm{H},{ }^{t} \mathrm{Bu}\right), 1.28\left(\mathrm{~s}, 18 \mathrm{H},{ }^{t} \mathrm{Bu}\right) ;{ }^{13} \mathrm{C}-\mathrm{NMR}(100 \mathrm{MHz}$, $\left.\mathrm{CDCl}_{3}, \delta_{\mathrm{C}}, \mathrm{ppm}\right): 158.0(C-\mathrm{O}), 139.3(\mathrm{Ar}), 138.6(\mathrm{Ar}), 124.8(\mathrm{Ar})$, $124.1(\mathrm{Ar}), 199.8(\mathrm{Ar}), 63.4\left(\mathrm{CH}_{2} \mathrm{~N}\right), 55.1\left(\mathrm{CH}_{2} \mathrm{~N}\right), 45.0\left(\mathrm{NCH}_{3}\right)$, $35.5\left(C\left(\mathrm{CH}_{3}\right)_{3}\right), 34.2\left(\mathrm{C}\left(\mathrm{CH}_{3}\right)_{3}\right), 32.0\left(\mathrm{C}\left(\mathrm{CH}_{3}\right)_{3}\right), 30.2\left(\mathrm{C}\left(\mathrm{CH}_{3}\right)_{3}\right)$. Elemental analysis (CHN): (calculated) C: $65.03 \%, \mathrm{H}: 8.67 \%, \mathrm{~N}$ : 4.46\% (experimental) C: $64.92 \%, \mathrm{H}: 8.80 \%, \mathrm{~N}: 4.57 \% . \operatorname{In}(2) \mathrm{Cl}$ (790 mg, $1.18 \mathrm{mmol}, 42 \%) .{ }^{1} \mathrm{H}-\mathrm{NMR}\left(400 \mathrm{MHz}, \mathrm{CDCl}_{3}, \delta_{\mathrm{H}}\right.$, ppm): 7.31 (d, $2.5 \mathrm{~Hz}, 2 \mathrm{H}, \mathrm{Ar}), 6.78$ (d, $2.5 \mathrm{~Hz}, 2 \mathrm{H}, \mathrm{Ar}), 4.81$ (d, $11.8 \mathrm{~Hz}, 2 \mathrm{H}, \mathrm{CH} H \mathrm{~N}$ ), 3.20 (d, $11.83 \mathrm{~Hz}, 4 \mathrm{H}, \mathrm{CHHN}), 2.93$ (m, $2 \mathrm{H}, \mathrm{NCH} H \mathrm{C}$ ), 2.40 (s, 6H, $\left.\mathrm{NCH}_{3}\right), 1.53\left(\mathrm{~s}, 18 \mathrm{H},{ }^{t} \mathrm{Bu}\right), 1.28(\mathrm{~s}, 18 \mathrm{H}$, $\left.{ }^{t} \mathrm{Bu}\right) ;{ }^{13} \mathrm{C}-\mathrm{NMR}\left(100 \mathrm{MHz}, \mathrm{CDCl}_{3}, \delta_{\mathrm{C}}, \mathrm{ppm}\right): 160.5(C-\mathrm{O}), 139.8$ (Ar), $138.3(\mathrm{Ar}), 129.3(\mathrm{Ar}), 128.4(\mathrm{Ar}), 64.3\left(\mathrm{CH}_{2} \mathrm{~N}\right), 55.4\left(\mathrm{CH}_{2} \mathrm{~N}\right)$, 
$43.8\left(\mathrm{NCH}_{3}\right), 35.2\left(C\left(\mathrm{CH}_{3}\right)_{3}\right), 33.9\left(C\left(\mathrm{CH}_{3}\right)_{3}\right), 31.7\left(\mathrm{C}\left(\mathrm{CH}_{3}\right)_{3}\right), 29.9$ $\left(\mathrm{C}\left(\mathrm{CH}_{3}\right)_{3}\right)$. Elemental analysis $(\mathrm{CHN})$, (calculated) C: $60.67 \%, \mathrm{H}$ : 8.09\%, N: 4.16\%, (experimental) C: $60.71 \%$, H: $8.14 \%$, N: $4.16 \%$.

\section{Crystallography}

All data were collected, at $150 \mathrm{~K}$, on a Rigaku SuperNova diffractometer using radiation $\operatorname{CuK} \alpha(\lambda=1.54184 \AA)$. Structures were solved by direct methods throughout and refined on $F^{2}$ data using the SHELXL-2014 suite of programs. All hydrogen atoms were included in idealised positions and refined using the riding model. Refinements was straightforward with only the following points that merit note: in $\mathrm{Al}(\mathbf{1}) \mathrm{Cl}$ one methyl group was disordered over two positions in a 55:45 ratio; $\mathrm{In}_{2}(\mathbf{1})_{2}(\mathrm{OH})(\mathrm{OEt})$ contains 1.5 molecules of solvent in the asymmetric unit and one ${ }^{t} \mathrm{Bu}$ group is disordered over two positions in a 50:50 ratio; $\operatorname{In}(2) \mathrm{Cl}$ contains two molecules of toluene in the asymmetric unit. One ${ }^{t} \mathrm{Bu}$ group in $\mathrm{Al}(2) \mathrm{Cl}$ was disordered over two sites in a $75: 25$ ratio and a partial occupancy hexane molecule $(75 \%)$ was observed in the asymmetric unit. Two of the ${ }^{t} \mathrm{Bu}$ moieties in $\mathrm{Ga}(2) \mathrm{Cl}$ were disordered over two sites in ratios of $80: 20$ and $60: 40$ ratio, respectively. Residual solvent in this structure $\{\mathrm{Ga}(2) \mathrm{Cl}\}$ bore a strong resemblance to a molecule of hexane (the recrystallisation solvent) but the electron density was smeared in a manner that suggested that disorder, above and beyond this smearing, was also prevalent. Thus, an approach involving a very restrained solvent model was abandoned in favour of employing PLATON SQUEEZE to address the guest solvent in $\mathrm{Ga}(2) \mathrm{Cl}$ and an allowance for one molecule of hexane in the motif has been made in the formula presented herein. Further for $\mathrm{Ga}(2) \mathrm{Cl}$ residual electron density in this structure is in the region of the ligand based on $\mathrm{O} 1$ and N1. Attempts were made to model this, but at a site occupancy of approximately $10 \%$ for a potential minor component (which seemed to be the cis isomer), the merit of disorder modelling was questionable, and hence abandoned. Interestingly, the raw frames of data suggested some crystal twinning. However, the data from integration of the data as a twin were not ultimately used, as the scale factor for the second twin component refined to approximately 5\%, with no tangible advantage to the overall convergence of the model.

\section{Ring-opening polymerisation (ROP) studies}

For polymerisations, under an argon atmosphere, the required monomer : catalyst: $\mathrm{NEt}_{3}: \mathrm{BnOH}$ ratio was suspended in toluene (10 mL) then heated up to $80{ }^{\circ} \mathrm{C}$ (upon which the mixture solubilised) and stirred. In all cases $1.0 \mathrm{~g}$ of $\mathrm{rac}$-LA was used. After the reaction time the vessel was opened to air and methanol (1-2 drops) was added to quench the reaction and the resulting solid was dissolved in dichloromethane. The solvents were removed in vacuo, an NMR spectrum was recorded to establish conversion. The crude mixture was washed with copious amounts of methanol to remove unreacted monomer to afford the pure polymer. ${ }^{1} \mathrm{H}$ NMR spectroscopy $\left(\mathrm{CDCl}_{3}\right)$ and GPC (THF) were used to determine tacticity and molecular weights $\left(M_{\mathrm{n}}\right.$ and $M_{\mathrm{w}}$ ) of the polymers produced; $P_{\mathrm{r}}$ (the probability of racemic linkages) values were determined by analysis of the methine region of the homonuclear decoupled ${ }^{1} \mathrm{H}$ NMR spectra. ${ }^{4 f}$ GPC were recorded on an Agilent instrument using triple detection and the multi analysis software. Polymer end-group analysis was carried out using MALDI-ToF spectrometry on a Bruker Autoflex speed instrument using DCTB (trans-2-[3-(4-tert-butylphenyl)2-methyl-2-propenylidene]malononitrile) as the matrix and ionised using NaOAc.

\section{Results and discussion}

\section{Complexes}

The complexes were prepared as shown in Scheme 1. They were isolated as colourless crystals in high purity, as confirmed by elemental analysis.

The Ga(III) and In(III) complexes (Scheme 1 and Fig. 1) were prepared via first synthesising the potassium salt of the ligand and subsequent reaction with the metal-halide. Attempts to prepare the potassium salt of the ligand with Me groups instead of ${ }^{t} \mathrm{Bu}$ on the aromatic ring were unsuccessful and an insoluble material was isolated, thus synthetic efforts were concentrated on $\mathbf{1} / 2 \mathrm{H}_{2}$. The $\mathrm{Al}$ (III) complex could more readily be synthesised utilising $\mathrm{AlCl}(\mathrm{Et})_{2}$ as the precursor. All complexes were recrystallised in hexane/toluene mixture, see Tables 1 and 2 for selected metric data. To the best of our knowledge these are the first examples of either a salan-In-Cl, salan-In-I or salan-Ga-Cl complex characterised in the solid-state. For $\operatorname{In}(\mathbf{1}) \mathrm{Cl} / \mathrm{I}$ the metal centres are seen to be in a pseudo square based pyramidal (sqp) geometry, which is exemplified by $\tau=0.32$ ffor $\operatorname{In}(\mathbf{1}) \mathrm{I}$ this is $0.28\}$. The $\tau$ value is used as an aid regarding the preference of the complex to form either a sqp structure or trigonal bipyramidal (tbp) one. ${ }^{21}$ This is analogous to the In-Cl complexes of Jacobsen's ligand previously discussed. ${ }^{13 a}$ For this literature complex the In-N bond lengths are 2.171(7) and 2.207(7) which are within 3 esds and can therefore be considered equivalent. However, for both

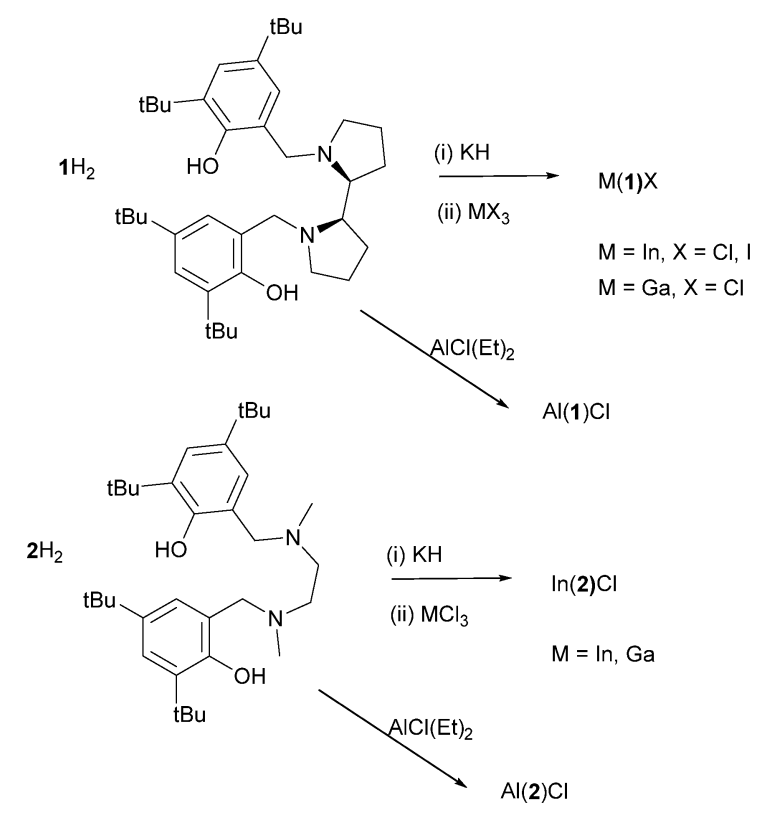

Scheme 1 Synthesis of complexes under investigation. 

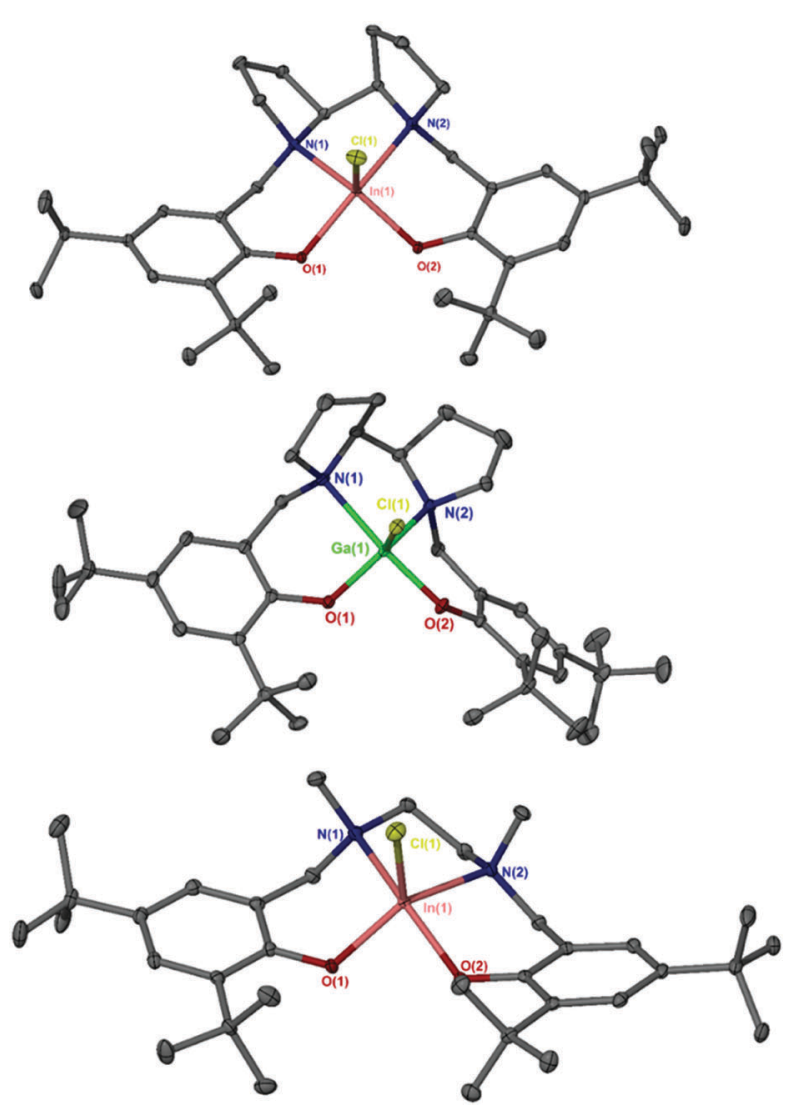

Fig. 1 Solid-state structure for $\ln (\mathbf{1}) \mathrm{Cl}, \mathrm{Ga}(\mathbf{1}) \mathrm{Cl}$ and $\ln (\mathbf{2}) \mathrm{Cl}$. Ellipsoids are shown at the $30 \%$ probability level and all hydrogen atoms have been removed for clarity.

Table 1 Selected bond lengths ( $\AA$ ) and angles ( $\left.{ }^{\circ}\right)$ for complexes with $\mathbf{1} \mathrm{H}_{2}$

\begin{tabular}{lllll}
\hline & $\mathrm{Al}(\mathbf{1}) \mathrm{Cl}$ & $\mathrm{Ga}(\mathbf{1}) \mathrm{Cl}$ & $\mathrm{In}(\mathbf{1}) \mathrm{Cl}$ & $\mathrm{In}(\mathbf{1}) \mathrm{I}$ \\
\hline $\mathrm{M}-\mathrm{X}$ & $2.1802(6)$ & $2.2043(4)$ & $2.3683(4)$ & $2.69445(19)$ \\
$\mathrm{M}-\mathrm{O}(1)$ & $1.7820(11)$ & $1.8436(10)$ & $2.0768(9)$ & $2.0536(14)$ \\
$\mathrm{M}-\mathrm{O}(2)$ & $1.7540(11)$ & $1.8828(10)$ & $2.0574(10)$ & $2.0907(14)$ \\
$\mathrm{M}-\mathrm{N}(1)$ & $2.0285(13)$ & $2.2527(11)$ & $2.2684(11)$ & $2.2723(17)$ \\
$\mathrm{M}-\mathrm{N}(2)$ & $2.2147(13)$ & $2.0513(12)$ & $2.3539(11)$ & $2.3719(16)$ \\
$\mathrm{N}(1)-\mathrm{M}-\mathrm{O}(2)$ & $126.79(6)$ & $122.74(5)$ & $134.92(4)$ & $134.49(6)$ \\
$\mathrm{O}(1)-\mathrm{M}-\mathrm{N}(2)$ & $167.65(5)$ & $168.58(4)$ & $154.02(4)$ & $151.10(6)$ \\
$\mathrm{N}(1)-\mathrm{M}-\mathrm{X}$ & $114.99(4)$ & $94.37(3)$ & $111.62(3)$ & $102.49(4)$
\end{tabular}

Table 2 Selected bond lengths ( $\AA$ ) and angles $\left(^{\circ}\right)$ for complexes with $2 \mathrm{H}_{2}$

\begin{tabular}{llll}
\hline & $\mathrm{Al}(2) \mathrm{Cl}$ & $\mathrm{Ga}(2) \mathrm{Cl}$ & $\mathrm{In}(2) \mathrm{Cl}$ \\
\hline $\mathrm{M}-\mathrm{X}$ & $2.1720(9)$ & $2.2073(6)$ & $2.3700(5)$ \\
$\mathrm{M}-\mathrm{O}(1)$ & $1.7789(18)$ & $1.8603(16)$ & $2.0310(13)$ \\
$\mathrm{M}-\mathrm{O}(2)$ & $1.7551(17)$ & $1.8411(13)$ & $2.0737(13)$ \\
$\mathrm{M}-\mathrm{N}(1)$ & $2.052(2)$ & $2.0873(18)$ & $2.3544(17)$ \\
$\mathrm{M}-\mathrm{N}(2)$ & $2.211(2)$ & $2.2344(18)$ & $2.2572(16)$ \\
$\mathrm{N}(1)-\mathrm{M}-\mathrm{O}(2)$ & $143.66(9)$ & $142.42(7)$ & $155.56(6)$ \\
$\mathrm{O}(1)-\mathrm{M}-\mathrm{N}(2)$ & $159.19(9)$ & $159.98(9)$ & $132.71(6)$ \\
$\mathrm{N}(1)-\mathrm{M}-\mathrm{X}$ & $103.78(6)$ & $104.74(5)$ & $97.55(4)$
\end{tabular}

$\operatorname{In}(\mathbf{1}) \mathrm{Cl} / \mathrm{I}$ and there is a significant difference between the In-N bond lengths e.g. $\operatorname{In}(\mathbf{1}) \mathrm{Cl} 2.2684(11)$ vs. 2.3539(11) $\AA$. For $\mathrm{Ga}(\mathbf{1}) \mathrm{Cl} \tau=0.76$ indicative of a distorted trigonal bipyramidal geometry at the metal centre, this is also the case for $\mathrm{Al}(\mathbf{1}) \mathrm{Cl}$ with $\tau=0.68$. Previously, we reported the complex $\mathrm{Al}(\mathbf{1})\left(\mathrm{O}^{\mathrm{i}} \mathrm{Pr}\right)$, which also afforded $\tau=0.68 .^{4 a}$ This tbp geometry is further exemplified by analysis of the angles between the two planes formed by the $\mathrm{C}_{6}$-aromatic rings, $\mathrm{Al}(\mathbf{1}) \mathrm{Cl}=133^{\circ}, \mathrm{Ga}(\mathbf{1}) \mathrm{Cl}=134^{\circ}$ whereas $\operatorname{In}(\mathbf{1}) \mathrm{Cl} / \mathrm{I}=161 / 158^{\circ}$. As a structural comparison $\mathrm{Al} / \mathrm{Ga} /$ $\mathrm{In}(2) \mathrm{Cl}$ were prepared. The solid state structure of $\mathrm{In}(2) \mathrm{Cl}$ is analogous to $\operatorname{In}(\mathbf{1}) \mathrm{Cl}$, with $\tau=0.38$ and similar metric data. However, there is a difference for $\mathrm{Al} / \mathrm{Ga}(2) \mathrm{Cl}$ with $\tau=0.26 / 0.29$ respectively indicating a preference for a square based pyramidal geometry in those cases. Interestingly, the $\mathrm{N}-\mathrm{Me}$ groups are effectively cis to each other in $\operatorname{In}(2) \mathrm{Cl}$, whereas in the solid-state structures for $\mathrm{Al} / \mathrm{Ga}(2) \mathrm{Cl}$ these groups are trans.

In all cases $\{\mathrm{bar} \mathrm{Al} / \mathrm{Ga}(2) \mathrm{Cl}\}$ the solid-state structures appear to be maintained in solution and the ligand remains "locked" once coordinated as evidenced by the formation of clear diastereotopic doublets in the ${ }^{1} \mathrm{H}$ NMR spectrum $\left(\mathrm{CDCl}_{3}\right.$, see ESI $\left.\dagger\right)$. Furthermore, there are two singlets in the aromatic region of ${ }^{1} \mathrm{H}$ NMR spectrum and six aromatic resonances in the ${ }^{13} \mathrm{C}\left\{{ }^{1} \mathrm{H}\right\}$ NMR spectrum indicating that both phenoxides are equivalent in solution. For the bipyrrolidine complexes there are four carbon $-\mathrm{CH}_{2}-$ resonances and one $-\mathrm{CH}-$ resonance present in the NMR spectrum. For $\mathrm{Al} / \mathrm{Ga}(2) \mathrm{Cl}$ there are clearly two species present in solution in approximately a $75: 25$ ratio for $\mathrm{Al}(2) \mathrm{Cl}$ and $95: 5$ for $\mathrm{Ga}(2) \mathrm{Cl}$. The major species has an NMR spectrum analogous to $\mathrm{In}(2) \mathrm{Cl}$ with one resonance for the $\mathrm{N}-\mathrm{CH}_{3}$ group, implying in solution the major species is most likely the cis isomer. The minor series has two $\mathrm{N}-\mathrm{CH}_{3}$ resonances and a more complex series of doublets for the methylene protons which is expected for the trans isomer. DOSY indicated that the two species in solution have analogous diffusion constants, $c a .6 .3 \times 10^{-10} \mathrm{~m}^{2} \mathrm{~s}^{-1}$, which would be expected for cis/trans isomers, thus ruling out possible monomer-dimer equilibria. In(1)I showed fluxionality on the NMR time scale and it was necessary to cool the sample to $253 \mathrm{~K}$ to obtain sharp resonances. This may be related to tbp-sbp exchanges in solution or cis-trans exchange processes.

Reaction of In(1)Cl with NaOEt, in an attempt to generate an alkoxide, led to an intractable mixture of products, as previously observed for a SalBinap-InCl complex of Mehrkhodavandi. ${ }^{13 b}$ However, we were able to isolate a bridged $\mathrm{In}-\mathrm{OH} / \mathrm{O}^{\mathrm{i}} \mathrm{Pr}$ complex (see ESI $\dagger$ ) although this was in low yield. The coordination motif of the ligand in this octahedral complex is analogous to that observed for similar meso-ligated group 4 complexes. ${ }^{4 a}$ Presumably, during the polymerisation the indium centre is 6 coordinate (ligand, lactide and polymer chain) thus this illustrates the likely coordination of ligand in the catalytically active species.

\section{Polymerisation studies}

The complexes were initially trialled for the polymerisation of rac-LA in toluene at conditions of 100:1:1:1 (LA:metal: $\left.\mathrm{BnOH}: \mathrm{NEt}_{3}\right)$ at $80{ }^{\circ} \mathrm{C}$, Table 3. These conditions are typical for $\mathrm{In}-\mathrm{Cl}$ initiated polymerisation, the exact role of $\mathrm{NEt}_{3} / \mathrm{BnOH}$ is open to debate and the reader is directed to the following for pertinent mechanistic studies with $\operatorname{InX}_{3}{ }^{12 b}$ Regardless of the exact mechanism, the polymerisation is initiated by benzyl alcohol and catalysed by the Indium complex (as confirmed by MALDI-ToF and the lack of activity observed when no In 
Table 3 Selected polymerisation data. Solvent $=$ toluene, $T=80{ }^{\circ} \mathrm{C}$ and time $=24 \mathrm{~h}$

\begin{tabular}{|c|c|c|c|c|c|c|c|}
\hline Catalyst & $M: I$ & Co-catalyst & Con. $^{a} / \%$ & Theor. $M_{\mathrm{n}}{ }^{b}$ & $M_{\mathrm{n}}^{c}$ & $\Xi^{c}$ & $P_{\mathrm{r}}^{d}$ \\
\hline $\operatorname{In}(\mathbf{1}) \mathrm{Cl}$ & $100: 1$ & $\mathrm{BnOH}: \mathrm{NEt}_{3}$ & 95 & 13800 & 17650 & 1.01 & 0.82 \\
\hline $\operatorname{In}(\mathbf{1}) \mathrm{Cl}$ & $100: 1$ & $\mathrm{BnOH}$ & 60 & 8750 & 9600 & 1.08 & 0.76 \\
\hline $\operatorname{In}(\mathbf{1}) \mathrm{Cl}$ & $300: 1$ & $\mathrm{BnOH}: \mathrm{NEt}_{3}$ & 95 & 41150 & 34350 & 1.07 & 0.80 \\
\hline $\operatorname{In}(\mathbf{1}) \mathrm{Cl}$ & $300: 1$ & $\mathrm{BnOH}$ & 30 & 13050 & 13950 & 1.02 & 0.84 \\
\hline $\operatorname{In}(\mathbf{1}) \mathrm{Cl}$ & $900: 1$ & $\mathrm{BnOH}: \mathrm{NEt}_{3}$ & 86 & 111550 & 77850 & 1.07 & 0.80 \\
\hline $\operatorname{In}(\mathbf{1}) \mathrm{Cl}$ & $900: 1$ & $\mathrm{BnOH}$ & 42 & 54550 & 10200 & 1.08 & 0.82 \\
\hline $\operatorname{In}(\mathbf{1}) \mathrm{I}$ & $300: 1$ & $\mathrm{BnOH}: \mathrm{NEt}_{3}$ & 48 & 20850 & 21650 & 1.08 & 0.67 \\
\hline $\operatorname{In}(2) \mathrm{Cl}$ & $100: 1$ & $\mathrm{BnOH}: \mathrm{NEt}_{3}$ & 95 & 13800 & 10450 & 1.10 & 0.73 \\
\hline
\end{tabular}

complex is present). Under these conditions and time (up to 5 days at $80{ }^{\circ} \mathrm{C}$ ) only the indium complexes displayed any polymerisation activity. With the $\mathrm{Ga} / \mathrm{Al}$ complexes only monomer was isolated after work up. This may well be related to the fact that the "smaller" Lewis acidic metals are screened from coordinating a molecule of lactide or the strength of the $\mathrm{M}-\mathrm{X}$ bond prevents the formation of the alkoxide.

Previous work has shown that the Al-O ${ }^{i} \mathrm{Pr}$ complex of $\mathbf{1 H}_{2}$ $\left\{\mathrm{Al}(\mathbf{1})\left(\mathrm{O}^{\mathrm{i}} \mathrm{Pr}\right)\right\}$ was active under melt conditions (75\% conversion after $48 \mathrm{~h}$ ) producing atactic PLA. ${ }^{4 a}$ In this present study the $\mathrm{Al} / \mathrm{Ga}-\mathrm{Cl}$ complexes were tested under melt conditions but failed to produce any polymer. However, there is a dramatic switch in selectivity and activity with In(III), which produced heterotactic PLA in $24 \mathrm{~h}$ in solution. Using $\mathrm{InCl}_{3}$ (with $\mathrm{NEt}_{3}: \mathrm{BnOH}$ at $100: 1: 1: 1\left\{\mathrm{LA}: \mathrm{In}: \mathrm{BnOH}: \mathrm{NEt}_{3}\right\}$ ) we achieved a conversion of $96 \%$ in toluene at $80{ }^{\circ} \mathrm{C}$ under the same time frame. ${ }^{12}$ The molecular weight of the resulting PLA was $17800 \mathrm{~g} \mathrm{~mol}^{-1}$ with a dispersity of 1.45 and, $P_{\mathrm{r}}=0.71$. The PLA produced with our complexes is more monodispersed, with increased tacticity control. Further, given the high purity and good control of molecular weight any activity caused by residual or generated $\mathrm{InCl}_{3}$ is unlikely.

In all indium cases PLA with a high heterotactic was observed, as indicated by an enhancement in the isi and sis tetrads in the ${ }^{1} \mathrm{H}\left\{{ }^{1} \mathrm{H}\right\}$ NMR spectrum (see ESI $\dagger$ ). It was observed that $\mathrm{In}(2) \mathrm{Cl}$ was significantly less selective than $\operatorname{In}(\mathbf{1}) \mathrm{Cl}$, thus polymerisation optimisation was performed with $\operatorname{In}(\mathbf{1}) \mathrm{Cl}$. Without the addition of $\mathrm{BnOH}$ and $\mathrm{NEt}_{3}$ no polymer could be observed, however, without the addition of $\mathrm{NEt}_{3}$ polymerisation still proceeded albeit at a significantly reduced conversion. With increasing monomer : catalyst ratio the appropriate increase in polymer $M_{\mathrm{n}}$ was observed, indicating a very well controlled polymerisation. This was further supported by very low dispersities in all cases. The MALDI-ToF of the PLA $100: 1: 1: 1$ at $80^{\circ} \mathrm{C}$ indicated the BnO- and $-\mathrm{H}$ end groups and the main repeat unit was $144 \mathrm{~g} \mathrm{~mol}^{-1}$ with a minor series with a repeat unit of $72 \mathrm{~g} \mathrm{~mol}^{-1}$ indicative of a low degree of transesterification (see Fig. SI12, ESI $\dagger$ ). Interestingly the iodide complexes afforded a significantly lower yield than the chloride. A similar trend was observed when using $\mathrm{InX}_{3}\left(\operatorname{InCl}_{3} v s . \mathrm{InI}_{3}\right){ }^{12 b}$ It was hypothesised that the halide remains in the coordination sphere of the indium centre and this accounts for the differences in reactivity.

\section{Conclusions}

In conclusion we have prepared the first examples of salan complexes of the form $\mathrm{M}-\mathrm{X}(\mathrm{X}=\mathrm{Cl}$, I and $\mathrm{M}=\mathrm{In}, \mathrm{Ga})$. There is a switch from trigonal bipyramidal to square based pyramid upon increasing the size of the cation for $1 \mathrm{H}_{2}$, whilst for $2 \mathrm{H}_{2}$ no such change is observed, illustrating the rich and diverse chemistry of the group 13 elements. This change, in part, is presumably related to the rigidity of the bipyrrolidine derived ligand system. For the first time we have shown that indiumsalan complexes can be effective initiators for the production of heterotactic PLA with narrow dispersities and controllable molecular weights, these results are complementary to the rich chemistry of In-salen complexes. This highlights the importance of the combination of metal/ligand in the rational design of initiators for the controlled ROP of cyclic esters.

\section{Acknowledgements}

We thank the University of Bath and EPSRC for funding (MDJ, JB), Roger and Sue Whorrod for supporting a fellowship for AB.

\section{Notes and references}

1 (a) P. J. Dijkstra, H. Z. Du and J. Feijen, Polym. Chem., 2011, 2, 520-527; (b) B. J. O'Keefe, M. A. Hillmyer and W. B. Tolman, J. Chem. Soc., Dalton Trans., 2001, 2215-2224; (c) R. H. Platel, L. M. Hodgson and C. K. Williams, Polym. Rev., 2008, 48, 11-63; (d) A. Sauer, A. Kapelski, C. Fliedel, S. Dagorne, M. Kol and J. Okuda, Dalton Trans., 2013, 42, 9007-9023.

2 (a) A. P. Gupta and V. Kumar, Eur. Polym. J., 2007, 43, 4053-4074; (b) L. T. Lim, R. Auras and M. Rubino, Prog. Polym. Sci., 2008, 33, 820-852; (c) K. M. Nampoothiri, N. R. Nair and R. P. John, Bioresour. Technol., 2010, 101, 8493-8501.

3 (a) D. Bourissou, S. Moebs-Sanchez and B. Martin-Vaca, C. R. Chim., 2007, 10, 775-794; (b) J. B. Zhu and E. Y. X. Chen, J. Am. Chem. Soc., 2015, 137, 12506-12509.

4 (a) M. D. Jones, L. Brady, P. McKeown, A. Buchard, P. M. Schafer, L. H. Thomas, M. F. Mahon, T. J. Woodman and J. P. Lowe, Chem. Sci., 2015, 6, 5034-5039; (b) M. D. Jones, S. L. Hancock, P. McKeown, P. M. Schafer, A. Buchard, L. H. Thomas, M. F. Mahon and J. P. Lowe, Chem. Commun., 2014, 50, 15967-15970; (c) A. Amgoune, C. M. Thomas and J. F. Carpentier, Macromol. Rapid Commun., 2007, 28, 693-697; (d) A. Amgoune, C. M. Thomas, S. Ilinca, T. Roisnel and J. F. Carpentier, Angew. Chem., Int. Ed. Engl., 2006, 45, 2782-2784; (e) A. Amgoune, C. M. Thomas, T. Roisnel and J. F. Carpentier, Chem. - Eur. J., 2006, 12, 169-179; $(f)$ B. M. Chamberlain, M. Cheng, D. R. Moore, T. M. Ovitt, E. B. Lobkovsky and G. W. Coates, J. Am. Chem. Soc., 2001, 123, 3229-3238; (g) M. H. Chisholm, J. Gallucci and K. Phomphrai, Chem. Commun., 2003, 48-49; (h) M. H. Chisholm, J. C. Gallucci and K. Phomphrai, Inorg. Chem., 2004, 43, 6717-6725; (i) A. J. Chmura, M. G. Davidson, C. J. Frankis, M. D. Jones and M. D. Lunn, Chem. Commun., 2008, 1293-1295; (j) Z. R. Dai, Y. Y. Sun, J. Xiong, X. B. Pan, N. Tang and J. C. Wu, Catal. Sci. Technol., 2016, 6, 515-520; 
(k) A. Stopper, J. Okuda and M. Kol, Macromolecules, 2012, 45, 698-704; (l) Y. Y. Sun, J. Xiong, Z. R. Dai, X. B. Pan, N. Tang and J. C. Wu, Inorg. Chem., 2016, 55, 136-143; (m) A. L. Zelikoff, J. Kopilov, I. Goldberg, G. W. Coates and M. Kol, Chem. Commun., 2009, 6804-6806.

5 C. K. Williams, L. E. Breyfogle, S. K. Choi, W. Nam, V. G. Young, M. A. Hillmyer and W. B. Tolman, J. Am. Chem. Soc., 2003, 125, 11350-11359.

6 (a) M. H. Chisholm, N. J. Patmore and Z. P. Zhou, Chem. Commun., 2005, 127-129; (b) H. Z. Du, A. H. Velders, P. J. Dijkstra, J. R. Sun, Z. Y. Zhong, X. S. Chen and J. Feijen, Chem. - Eur. J., 2009, 15, 9836-9845; (c) P. Hormnirun, E. L. Marshall, V. C. Gibson, A. J. P. White and D. J. Williams, J. Am. Chem. Soc., 2004, 126, 2688-2689; (d) N. Nomura, R. Ishii, M. Akakura and K. Aoi, J. Am. Chem. Soc., 2002, 124, 5938-5939; (e) N. Spassky, M. Wisniewski, C. Pluta and A. LeBorgne, Macromol. Chem. Phys., 1996, 197, 2627-2637; (f) M. Wisniewski, A. LeBorgne and N. Spassky, Macromol. Chem. Phys., 1997, 198, 1227-1238; (g) Z. Y. Zhong, P. J. Dijkstra and J. Feijen, Angew. Chem., Int. Ed. Engl., 2002, 41, 4510-4513; (h) Z. Y. Zhong, P. J. Dijkstra and J. Feijen, J. Am. Chem. Soc., 2003, 125, 11291-11298.

7 K. M. Osten, D. C. Aluthge and P. Mehrkhodavandi, Dalton Trans., 2015, 44, 6126-6139.

8 (a) E. L. Whitelaw, G. Loraine, M. F. Mahon and M. D. Jones, Dalton Trans., 2011, 40, 11469-11473; (b) K. Nie, W. K. Gu, Y. M. Yao, Y. Zhang and Q. Shen, Organometallics, 2013, 32, 2608-2617; (c) A. Pilone, N. De Maio, K. Press, V. Venditto, D. Pappalardo, M. Mazzeo, C. Pellecchia, M. Kol and M. Lamberti, Dalton Trans., 2015, 44, 2157-2165; (d) A. Pilone, K. Press, I. Goldberg, M. Kol, M. Mazzeo and M. Lamberti, J. Am. Chem. Soc., 2014, 136, 2940-2943; (e) I. D. Vieira, E. L. Whitelaw, M. D. Jones and S. Herres-Pawlis, Chem. - Eur. J., 2013, 19, 4712-4716.

9 (a) C. Bakewell, T. P. A. Cao, X. F. Le Goff, N. J. Long, A. Auffrant and C. K. Williams, Organometallics, 2013, 32, 1475-1483; (b) T. P. A. Cao, A. Buchard, X. F. Le Goff, A. Auffrant and C. K. Williams, Inorg. Chem., 2012, 51, 2157-2169.

10 S. Dagorne, M. Normand, E. Kirillov and J. F. Carpentier, Coord. Chem. Rev., 2013, 257, 1869-1886.

11 (a) J. C. Buffet, J. Okuda and P. L. Arnold, Inorg. Chem., 2010, 49, 419-426; (b) A. Kapelski and J. Okuda, J. Polym. Sci., Part A: Polym. Chem., 2013, 51, 4983-4991; (c) I. Peckermann, A. Kapelski, T. P. Spaniol and J. Okuda, Inorg. Chem., 2009, 48, 5526-5534.

12 (a) A. Pietrangelo, M. A. Hillmyer and W. B. Tolman, Chem. Commun., 2009, 2736-2737; (b) A. Pietrangelo, S. C. Knight,
A. K. Gupta, L. J. Yao, M. A. Hillmyer and W. B. Tolman, J. Am. Chem. Soc., 2010, 132, 11649-11657.

13 (a) D. C. Aluthge, B. O. Patrick and P. Mehrkhodavandi, Chem. Commun., 2013, 49, 4295-4297; (b) D. C. Aluthge, E. X. Yan, J. M. Ahn and P. Mehrkhodavandi, Inorg. Chem., 2014, 53, 6828-6836; (c) A. F. Douglas, B. O. Patrick and P. Mehrkhodavandi, Angew. Chem., Int. Ed. Engl., 2008, 47, 2290-2293; (d) A. B. Kremer, K. M. Osten, I. Yu, T. Ebrahimi, D. C. Aluthge and P. Mehrkhodavandi, Inorg. Chem., 2016, 55, 5365-5374; (e) K. M. Osten, D. C. Aluthge, B. O. Patrick and P. Mehrkhodavandi, Inorg. Chem., 2014, 53, 9897-9906; $(f)$ K. M. Osten, I. S. Yu, I. R. Duffy, P. O. Lagaditis, J. C. C. Yu, C. J. Wallis and P. Mehrkhodavandi, Dalton Trans., 2012, 41, 8123-8134; (g) C. L. Xu, I. S. Yu and P. Mehrkhodavandi, Chem. Commun., 2012, 48, 6806-6808; (h) I. Yu, A. AcostaRamirez and P. Mehrkhodavandi, J. Am. Chem. Soc., 2012, 134, 12758-12773; (i) D. C. Aluthge, J. M. Ahn and P. Mehrkhodavandi, Chem. Sci., 2015, 6, 5284-5292.

14 (a) C. Bakewell, A. J. P. White, N. J. Long and C. K. Williams, Inorg. Chem., 2013, 52, 12561-12567; (b) S. Ghosh, R. R. Gowda, R. Jagan and D. Chakraborty, Dalton Trans., 2015, 44, 10410-10422; (c) P. Horeglad, M. Cybularczyk, B. Trzaskowski, G. Z. Zukowska, M. Dranka and J. Zachara, Organometallics, 2015, 34, 3480-3496; (d) P. Horeglad, A. Litwinska, G. Z. Zukowska, D. Kubicki, G. Szczepaniak, M. Dranka and J. Zachara, Appl. Organomet. Chem., 2013, 27, 328-336.

15 N. Maudoux, J. Fang, T. Roisnel, V. Dorcet, L. Maron, J. F. Carpentier and Y. Sarazin, Chem. - Eur. J., 2014, 20, 7706-7717.

16 C. Bakewell, A. J. P. White, N. J. Long and C. K. Williams, Angew. Chem., Int. Ed. Engl., 2014, 53, 9226-9230.

17 (a) T. M. Ovitt and G. W. Coates, J. Am. Chem. Soc., 2002, 124, 1316-1326; (b) D. Pappalardo, M. Bruno, M. Lamberti, M. Mazzeo and C. Pellecchia, J. Mol. Catal. A: Chem., 2013, 379, 303-308.

18 E. Sergeeva, J. Kopilov, I. Goldberg and M. Kol, Chem. Commun., 2009, 3053-3055.

19 (a) K. Press, I. Goldberg and M. Kol, Angew. Chem., Int. Ed. Engl., 2015, 54, 14858-14861; (b) T. Rosen, I. Goldberg, V. Venditto and M. Kol, J. Am. Chem. Soc., 2016, 138, 12041-12044.

20 A. J. Chmura, M. G. Davidson, M. D. Jones, M. D. Lunn, M. F. Mahon, A. F. Johnson, P. Khunkamchoo, S. L. Roberts and S. S. F. Wong, Macromolecules, 2006, 39, 7250-7257.

21 D. A. Atwood, A. R. Hutchison and Y. Zhang, in Group 13 Chemistry III: Industrial Applications, ed. H. W. Roesky and D. A. Atwood, Springer Berlin Heidelberg, Berlin, Heidelberg, 2003, pp. 167-201. 